YABANCI DIL SON SINIF ÖĞRENCILERINIIN OKUMA ALIŞKANLIKLARI ÜZERINE DURUM TESPITI ÇALIŞMASI ${ }^{1}$

Harun GÖÇERLER ${ }^{2}$

\begin{tabular}{|c|c|}
\hline Makale Bilgisi & \\
\hline DOI: 10.19171/uefad.737648 & \multirow{6}{*}{ 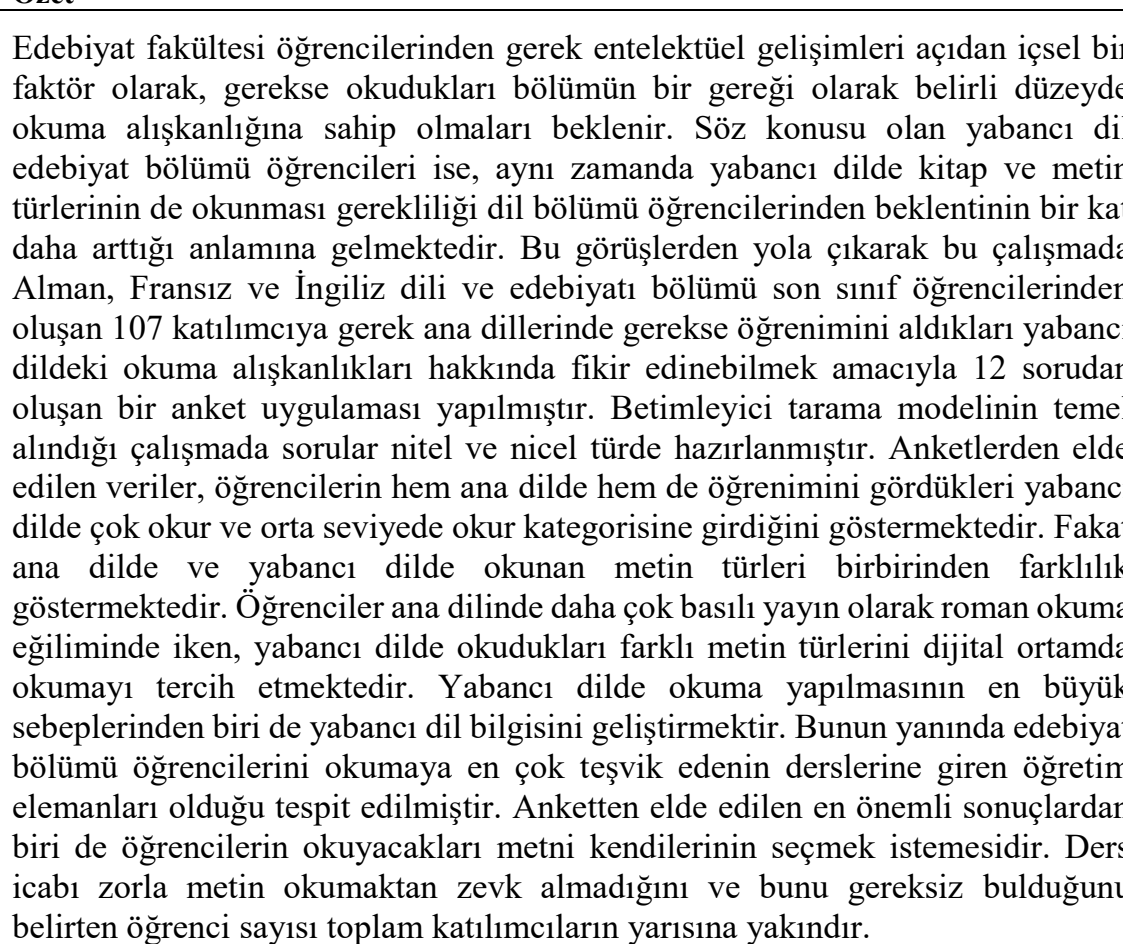 } \\
\hline Makale Geçmişi: & \\
\hline 14.05 .2020 & \\
\hline 15.10 .2020 & \\
\hline Anahtar Kelimeler: & \\
\hline $\begin{array}{l}\text { Okuma, yabancı dil, } \\
\text { okuma alıskkanlığ, } \\
\text { edebiyat bölümü. }\end{array}$ & \\
\hline
\end{tabular}

\title{
A CASE STUDY ON READING HABITS OF SENIOR FOREIGN LANGUAGE UNIVERSITY STUDENTS
}

\begin{tabular}{|c|c|}
\hline Article Info & bstract \\
\hline ad. 737648 & \multirow{6}{*}{$\begin{array}{l}\text { Students of Faculty of Letters are expected to have a certain level of reading habits } \\
\text { both as an internal factor in intellectual development, and as a requirement of their } \\
\text { department. Expectations from students in foreign language departments about } \\
\text { the necessity of reading foreign language books and text types have increased } \\
\text { recently. This descriptive survey study aimed to investigate the native and foreign } \\
\text { language reading habits of } 107 \text { senior students in Tekirdag Namik Kemal } \\
\text { University, Faculty of Arts and Letters, German, French and English Literature } \\
\text { Departments.. To this aim, a survey of } 12 \text { qualitative and quantitative questions } \\
\text { was developed and administered to the participants prepared. Findigs showed that } \\
\text { students fell into the category of advanced and moderate level readers in both } \\
\text { native and foreign language. However, text types read in native and foreign } \\
\text { language differed. Whereas students tended to read native language novels more } \\
\text { in published form, they prefered to read different foreign language different text }\end{array}$} \\
\hline Article History: & \\
\hline Received $\quad 14.05 .2020$ & \\
\hline Accepted $\quad 15.10 .2020$ & \\
\hline Keywords: & \\
\hline $\begin{array}{l}\text { Reading habit, foreign } \\
\text { language, reading, } \\
\text { literature department. }\end{array}$ & \\
\hline
\end{tabular}

\footnotetext{
${ }^{1}$ Bu araştırma makalesine ait anket çallş̧masının etik kurul onayı Tekirdă̆ Namık Kemal Üniversitesi Bilimsel Araştırma ve Yayın Etik Kurulu Başkanlı̆̆ı'ndan T2020-408 Sayı numarası ile alınmıştır.

${ }^{2}$ Dr. Ögrr. Üyesi., Tekirdağ Namık Kemal Üniversitesi, hgocerler@nku.edu.tr, OrcID: 0000-0002-2394-3795
} 
types in digital media. One of the most significant reasons reported for reading in a foreign language was to develop foreign language knowledge. It was also found that the most encouraging factor for students in literature departments was the lecturers. One of the most important results of the survey is that students wantd to choose the reading text themselves. Almost half the participants stated that they did not enjoy reading compulsory texts as a requirement of courses and found it unnecessary.

\section{GíRiş}

Bilginin günlük hayatımızda sürekli evrilerek artması, 20. yüzyıla nazaran daha mobil hale gelen insanlar arasındaki iletişimin bilgiye ve genel kültüre dayalı olarak daha sağlam temeller üzerinde yapılandırılması, temelde okuma eyleminin de içinde bulunduğu birçok etkinlik sayesinde şekillenmektedir. Odabaş, Odabaş ve Polat (2008: 433)'a göre okuma eylemi; "Belirli dilsel kurallara uyularak oluşturulmuş yazılı iletileri duyu organları yoluyla algılayıp kavrama, anlamlandırma, yorumlama, düşünce üretme ve yarglya varma evrelerinden oluşan bütünsel bir süreç”tir. Bu eylem, kişiyi çağımız modern insanı haline getiren en etkili araçlardan biri olmuştur.

Çağımız modern insanı kavramı kullanılırken, nitelikli okuma alışkanlığına sahip olan, okuduğunu anlayan, doğru yorumlayan ve öğrendiklerini sürekli geliştiren, meraklı ve düşünen bireylerin kastedildiği unutulmamalıdır (Çoban, İleri \& Temir, 2018: 52). Bu düşünce ile günümüz eğitim sistemlerinin başlıca hedefinin bilgiye ulaşma yollarının kazandırılmasının yanında, onu ilerletme, yorumlama ve kişisel gelişime destek olma gibi araştırmaları teşvik etmek olduğu düşünülürse, çağımız modern insanının temelde hangi özelliklere sahip olması gerektiği de ortaya çıkmış olur. Tam da bu noktada eğitim sistemimiz içinde öncelikle eğitimcilere düşen en önemli görev, yaşam boyu öğrenme bilincini öğrencilerine aşılamak için okuma alışkanlığının bireysel ve istendik bir tercih haline gelmesini sağlamaktır.

Çoban ve ark. (2018: 53) göre; “medeni insanın önemli ve sürekli ihtiyaçlarından olan okumanın bir alışkanlık haline gelmesi, kişinin günlük hayatının vazgeçilmez bir bireysel eyleme dönüşmesi okuma alışkanlığı olarak nitelendirilir”. Fakat bunun bir alışkanlık halini almasının belki uzun yıllar alabilecek bir süreç olduğunu unutmamak gerekir (Aksaçlıoğlu \& Yılmaz, 2007: 5). Nitekim bu alışkanlığın kazanılmasındaki en önemli dönem "bedensel ve ruhsal değişmelerin yoğun biçimde yaşandığı çocukluk ve gençlik dönemleridir” (Yılmaz, Köse \& Korkut, 2009: 22). Konuya bu açıdan yaklaşıldığında okumanın "aslen kolay öğrenilen, fakat alışkanlık haline gelmesi, birçok duyuşsal özelliklerin bir araya gelmesi ile mümkün olan bir eylem olduğunu belirtmek yerinde olacaktır” (Arslan, Çelik \& Çelik, 2009: 114). Bu yüzden 
bireylere okuma alışkanlığı kazandırma amacının, ilköğretim yıllarından yükseköğretime kadar eğitim sisteminin her aşamasında üzerinde ciddiyetle durulması gereken bir konu olduğu aşikârdır.

Okuma alışkanlığı konusu dil ve kültür edinimi, boş zaman aktivitesi, akademik gereklilikler, merak, kişisel gelişim, günlük rutinden kurtulma isteği gibi birçok farklı başlık altında ele alınıp incelenebilecek geniş kapsamlı bir olgudur. Günlük yaşamımızda adım attığımız her mekânda, mutlaka okuyacak bir nesne görmekteyiz. Bilgi edinme hedefi ile olsun ya da olmasın, hayatın her adımında bilinçli ya da bilinçsizce yapılan yüzlerce okuma, bazen insanların iradeleri dışında birçok bilgiyi bilinçaltına kaydetmelerine vesile olur. Günlük hayatta karşılaşılan okuma imkânlarının farklılığı ve çok boyutluluğu, aynı zamanda insanların okuma seçimlerinin ne kadar farklı ve geniş olabileceğini de göstermektedir. Bu bağlamda okuma kavramının insanların zihninde değişip yeni bir boyut kazanmasına yol açan teknolojik yeniliklerin etkilerinin de okumada çok çeşitlilik ve tercih imkânlarının yelpazesinin genişlemesi anlamında göz ardı edilmemesi gerekir. Teknolojik gelişmeler sonucunda ortaya çıkan sosyo-kültürel akımlar ve yeni teknolojik araçların insanların bunları yeni hedeflerle kullanma alışkanlıklarının yaygınlaşmasının boş zaman aktivitelerinde, okulda, yeni öğrenme çeşitlerinde ve tabii ki gençlerin belki de iyi bir eğitim süreci geçirmelerinin en anlamlı noktası olan okuma alışkanlıklarında da yansımaları olmuştur (Göçerler, Atik \& Demir, 2017: 264).

Fakat okuma olgusu özelinde söz konusu olan, karşımıza çıkan her türlü yazıyı okuyup okumamaktan öte, okuduğumuz yazıların hangi niteliklere sahip olduğu ve okuyanın yazıya hangi bakış açısıyla yaklaştığıdır (Bayat \& Çetinkaya, 2018: 986). Bu durum da kendi içerisinde zamanla kazanılabilen belli kabiliyetler ve stratejiler gerektirir. Bireylerin sadece kendi dillerinde yazılan ürünleri okumaları değil, aynı zamanda farklı dillerde yazılmış olan ürünleri de okumaları onların hayata bakış açılarının gelişmesine, farklı kültürel öğelerin günlük hayattaki önemini kavramalarına, toplam kişilik gelişimine ve makro düzeyde ise toplumsal bilincin de farklı konularda çeşitlenip renklenmesine vesile olacaktır.

Bu anlamda nitelikli okuma kabiliyetine sahip olması gereken kitlelerin en başında belki de üniversitelerimizde edebiyat bölümlerinde öğrenim görmüş ya da görmekte olan gençlerin gelebileceği söylenebilir. Bu bağlamda, söz konusu grup özellikle yabancı dil alanında edebiyat tahsili görüyor ise, kendi dilinde edinmiş olması gereken nitelikli okuma kabiliyetinin yanı sıra yabancı dilde okuma alışkanlığ̣ da kazanmış olmalıdır. Çünkü "ana dilde çok okuyan bir öğrenci, yabancı dilde de bu alışkanlığını yitirmeyecek ve daha çok öğrenecek, sözcük dağarcığını genişleterek, okuduğunu çözümleyecek ve anlayacaktır” (Genç, 1995: 74). 
Edebiyat bölümü öğrencileri ancak söz konusu kabiliyet ve alışkanlık sayesinde farklı bir kültürün ürünü olan eserleri anlayıp yorumlayabilir, o eserlerden çıkarımlarda bulunabilir ve o çıkarımları kişisel gelişim süreçlerinin birer parçası sayabilir. Nihayetinde zaman içerisinde içinde yaşadıkları topluma da sosyo-kültürel anlamda renk katabilirler.

Fakat tüm bunların yanında yabancı dil alanında edebiyat bölümlerinde öğrenim gören gençler, okuma alışkanlığına sahip olsalar ya da nitelikli okuma becerilerini ana dillerindeki okuma etkinlikleri ile geliştirebilmiş olsalar bile, yeterli yabancı dil becerisine de sahip değilseler, okuma süreci daha başlamadan bitmiş denebilir. Bu düşüncelerden yola çıkarak bu araştırmada Tekirdağ Namık Kemal Üniversitesi Fen-Edebiyat Fakültesi Alman Dili ve Edebiyat1, Fransız Dili ve Edebiyatı ile İngiliz Dili ve Edebiyatı bölümleri son sınıf öğrencilerinden oluşan 107 katılımcıya yabancı dilde kitap okuma alışkanlıkları hakkında nitel ve nicel sorular içeren anket çalışması uygulanmıştır. Çalışma, öğrencilerin üniversite öğrenimleri boyunca yabancı dilde okuma alışkanlıkları özelinde gelişim gösterip gösteremediklerini yine onların gözünden tespit etmeyi amaçlamaktadır.

\section{YÖNTEM}

\subsection{Araştırmanın Amacı}

$\mathrm{Bu}$ araştırmanın amacı, üniversite son sınıfta yabancı dil edebiyat öğrenimi görmekte olan öğrencilerin anadilde ve öğrenimini görmekte oldukları yabancı dildeki okuma alışkanlıklarına dair tespitlerde bulunmak, ayrıca öğrencilerin okuma alışkanlıklarının gelişmesi sürecinde etkili olan faktörler üzerine görüşler elde etmek ve çözüm önerileri sunmaktır. Çalışmada asıl hedef, katılımcıların her ne kadar yabancı dildeki okuma alışkanlıklarına dair verileri tespit etmek olsa da onların ana dillerindeki okuma alışkanlıklarına yönelik sorular da mevcuttur. Çünkü bir okuyucunun ana dilindeki okuma becerisinin ikinci ya da yabancı dildeki okuma becerisinin gelişimi için bir etken olduğu birçok araştırmacı tarafindan savunulan bir durumdur (Durmuşçelebi \& Sarıcaoğlu, 2009: 3; Pekkanlı \& Kartal, 2010: 92)

Araştırmaya katılımcı olarak destek vermeyi kabul eden örneklem grubundan olduğu gibi, evren grubundan da beklenen, edebiyat bölümü öğrencisi olarak yükseköğrenim kurumunda geçirdikleri süre boyunca öğrenimini gördükleri dilde, anadilinde olduğu kadar olmasa da belli bir düzeyde okuma alışkanlığı geliştirebilmiş olmalarıdır. Eğer bu alışkanlığın gelişmemesi gibi bir durum söz konusu ise, buna sebep olan faktörlerin de anket katılımcılarının 
bakış açısından ortaya konulması ve çözüm önerileri sunmak da bu araştırmanın ikincil hedefidir.

\subsection{Araştırma Grubu ve Yöntem}

Bu araştırma, Tekirdağ Namık Kemal Üniversitesi Fen-Edebiyat Fakültesi Alman Fransız ve İngiliz Dili ve Edebiyatı Anabilim Dalında lisans öğrenimi görmekte olan son sınıf öğrencilerine çoktan seçmeli şıklardan birini seçmeleri ve aynı soruya yönelik olarak fikirlerini aktarabilecekleri şekilde kurgulanan toplam 12 sorudan meydana gelen ve betimleyici tarama modeli temelinde hazırlanan bir anket yoluyla toplanan verilere dayanarak yapılmıştır. Anket çalışmasının etik kurul onayı Tekirdağ Namık Kemal Üniversitesi Bilimsel Araştırma ve Yayın Etik Kurulu Başkanlığı'ndan 20.02.2020 tarihli 2020-408 Sayı numarası ile alınmıştır.

Araştırmaya Almanca bölümünden 31, Fransızca ve İngilizce bölümlerinden ise 38'er öğrenci katılım sağlamıştır. Gönüllülük esasına göre ankete katılım sağlayan toplam 107 öğrencinin genel olarak kitap okuma alışkanlığının olup olmadığı, okuduğu kitapları hangi kanallardan temin ettiği, okuduğu metinlerde dijital mi yoksa analog okumayı mı tercih ettiği, anadilinde ve eğitimini aldığı yabancı dilde kitap okuma alışkanlığı olup olmadığı, yılda kaç kitap okuduğu, eğitimini aldığı yabancı dilde kitap haricinde ne tür metinler okumayı tercih ettiği, kitap okumuyorsa sebebi, kitap okumanın kişilik gelişimine katkı sağlayıp sağlamayacağı konusunda öğrencilerin görüşü, yükseköğrenimleri süresince kendilerini okumaya özendiren faktörler gibi sorular yöneltilmiştir.

Nitel ve nicel sorulardan oluşan karma sormaca yöntemine dayalı söz konusu araştırma ile elde edilen nicel verilerin, öğrenciler tarafından aktarılan nitel veriler ile de desteklenmesi hedeflenmiştir. $\mathrm{Bu}$ amaç, karma araştırma yönteminin genel özellikleri ile de paralellik göstermektedir (Baki \& Gökçek, 2012).

Araştırmada veri toplamada araç olarak kullanılan anket, araştırmacı tarafindan oluşturulmuştur. "Anketler, ölçekten farklı olduğu için, bir toplam veya ortalama puandan bahsetmek mümkün değildir. Bu nedenle ölçeklerdeki gibi teknik anlamda güvenirlik ve geçerlilik kavramlarından söz edilememektedir" (Çoban \& ark, 2018: 56). Bu araştırmada, kullanılan ölçme aracı bir anket olduğu için güvenirlik analizi de yapılmamıştır. 


\section{BULGULAR VE YORUMLAR}

$\mathrm{Bu}$ kısımda, anket sorularından elde edilen veriler aktarılacak ve her bir sonuçtan sonra gerekli görülen kısımlar için yorumlara da yer verilecektir.

\subsection{Genel Olarak Okunan Kitap Türleri}

Okuduğu kitap türünü genel olarak "roman” başlığı altında sınıflandıran 28 kişi olduğu görülürken, bunu alt başlıklarda detaylı olarak sunan öğrencilerin okuduğu türler aşağıdaki tabloda belirtilmiştir. Öğrencilere yöneltilen soruda ne tarz kitaplar okudukları sorulduğundan dolayı, öğrenciler cevaplarda tek bir kitap türü vermek yerine, okumayı sevdikleri türleri sıralamayı tercih etmiştir. Bundan dolayı öğrenciler tarafından en çok tercih edilen kitap türleri anketlere verilen cevaplardaki sayılara göre sıralanmıştır. Aşağıdaki verilerin incelenmesinde her bir öğrencinin birden fazla edebî metin türünü okuduğunu belirtmiş olduğu göz önüne alınmalıdır. Buna bir öğrenci iki edebî ürün türünü okuduğunu belirtirken, bir başkası dört ya da beş farklı türde edebî ürün okuduğunu dile getirmiş olabilir.

Tablo 1

Katılımcıların hangi tarz kitaplar okumayı tercih ettiklerini gösteren tablo

\begin{tabular}{|c|c|c|c|c|c|}
\hline Klasikler & Bilim Kurgu & Roman & Fantastik & Psikolojik & Polisiye \\
\hline $\begin{array}{c}f: 42 \\
(\% 44.94)\end{array}$ & $\begin{array}{c}f: 28 \\
(\% 29.96)\end{array}$ & $\begin{array}{c}f: 28 \\
(\% 29.96)\end{array}$ & $\begin{array}{c}f: 18 \\
(\% 19.26)\end{array}$ & $\begin{array}{c}f: 18 \\
(\% 19.26)\end{array}$ & $\begin{array}{c}f: 17 \\
(\% 18.19)\end{array}$ \\
\hline Felsefe & Tarih & $\begin{array}{l}\text { Kişisel } \\
\text { Gelişim }\end{array}$ & Macera & Otobiyografi & Distopik kitaplar \\
\hline $\begin{array}{c}f: 16 \\
(\% 17.12)\end{array}$ & $\begin{array}{c}f: 13 \\
(\% 13.91)\end{array}$ & $\begin{array}{c}f: 10 \\
(\% 10.07)\end{array}$ & $\begin{array}{c}f: 10 \\
(\% 10.07)\end{array}$ & $\begin{array}{c}f: 8 \\
(\% 8.56)\end{array}$ & $\begin{array}{c}f: 6 \\
(\% 6.42)\end{array}$ \\
\hline Şiir & Gerilim & Deneme & Kısa Öykü & Siyasi & Romantik \\
\hline $\begin{array}{c}f: 6 \\
(\% 6.42)\end{array}$ & $\begin{array}{c}f: 6 \\
(\% 6.42)\end{array}$ & $\begin{array}{c}f: 5 \\
(\% 5.35)\end{array}$ & $\begin{array}{c}f: 5 \\
(\% 5.35)\end{array}$ & $\begin{array}{c}f: 3 \\
(\% 3.21)\end{array}$ & $\begin{array}{c}f: 3 \\
(\% 3.21)\end{array}$ \\
\hline Komedi & Yeraltı edebiyatı & Dini & Finans & Araştırma Yazıları & \\
\hline $\begin{array}{c}f: 2 \\
(\% 2.14)\end{array}$ & $\begin{array}{c}f: 2 \\
(\% 2.14)\end{array}$ & $\begin{array}{c}f: 1 \\
(\% 1.07)\end{array}$ & $\begin{array}{c}f: 1 \\
(\% 1.07)\end{array}$ & $\begin{array}{c}f: 1 \\
(\% 1.07)\end{array}$ & \\
\hline
\end{tabular}

Anket sorusuna verilen cevaplarda roman, 28 öğrenci tarafından tek bir kategoride ele alınsa da klasikler, bilim kurgu, fantastik, psikolojik, macera, gerilim, deneme, romantik, yer altı edebiyatı gibi alt başlıklar da romanın alt sınıfları olarak ele alındığında öğrencilerin en severek okudukları türün roman olduğu ortaya çıkmıştır. Fakat alt kategori olarak ise tüm 
öğrenciler arasında en sevilen roman türünün klasikler olduğu anlaşılmaktadır. Roman türleri dışında, öğrencilerce en tercih edilen tarz olarak tarih kitapları gelmektedir.

\subsection{Kitapların Hangi Kanallardan Edinildiği}

Tablo 2

Okunan kitapların hangi yollardan temin edildiğini gösteren tablo

\begin{tabular}{lcc} 
Illk elden satın almak & Frekans & Yüzde \\
Dijital Medya & $f: 81$ & $(\% 86.67)$ \\
\hline Kütüphane & $f: 36$ & $(\% 38.52)$ \\
\hline Korsan yayın satın almak & $f: 22$ & $(\% 23.54)$ \\
\hline
\end{tabular}

Şıklara verilen cevaplardan yola çıkarak, ankete katılım sağlayan öğrencilerin okudukları kitapları tek bir kanaldan değil, farklı kanallardan temin etme yolunu seçtikleri anlaşılmaktadır. Temin yolları arasında en popüler olan ise öğrencilerin orijinal kitap almaya gayret etmeleridir. Orijinal basılı kitap almayan öğrencilerin ise metinleri dijital medya yoluyla temin ettikleri ya da kütüphaneden ödünç aldıkları görülmektedir. Korsan yayın satın almak durumunda olduğunu belirten öğrenci sayısı ise beştir.

Ankete katılanların hepsinin belirli bir ekonomik gelir sınıfina ait ve ekonomik olarak çoğunlukla dış kaynaklara bağlı bireyler olduğu göz önünde bulundurulduğunda, büyük çoğunluğun orijinal kitap almayı tercih ediyor olması takdir edilmesi gereken bir durumdur. $\mathrm{Bu}$ sonuçtan anlaşılıyor ki ankete katılan edebiyat bölümü öğrencileri edebî eserin üretim sürecine ve verilen emeğe saygı duymaktalar.

\subsection{Tercih Edilen Metin Türlerinin Hangi Ortamda Okunduğu ve Sebepleri}

Yirmi öğrenci edinmiş oldukları metinleri dijital ortamda okumayı tercih ettiğini belirtmiştir. Bunun sebebi olarak ise dijital ortamın her yerde pratik okuma olanağı sunması ( $f$ : 4), dijital kitapların kolay temin edilebilmesi (f: 4), dijital kitapların basılı kitaplara nazaran daha uygun fiyatlı olması (f: 5), aynı zamanda karanlıkta okumak açısından daha konforlu olması (f: 1), kolay taşınabilmesi $(f: 1)$ ve öğrencinin Kindle sahibi olması $(f: 1)$ öne sürülmektedir.

Fakat ankete katılım sağlayan kişi sayısının 107 olduğu göz önünde bulundurulduğunda yabancı dil edebiyat bölümü öğrencilerinin büyük çoğunluğunun $(f: 87)$ basılı kitap okumayı tercih ettiği görülmektedir. Öğrencilerin basılı kitap okumayı tercih etme sebepleri arasında ise 
kâğıda dokunmak, kâğıt kokusunu hissetmek ve kâğıttan okumaktan zevk almak birinci tercih sebebi olmuştur (f: 37). İkinci olarak, öğrenci kâğıttan okurken dijital okumaya nazaran daha iyi odaklanabildiklerini dile getirmiştir ( $f: 14)$. Kendi kütüphanesini kurmak niyetinde olduğunu belirten (f: 11) ve göz sağlığını korumak için kâğıttan okumayı tercih ettiğini ( $f: 11)$ söyleyenlerin sayısı eşittir. Tüm bu sebeplerin dışında, basılı metinler okuyucuya kolayca not alabilme olanağı sunduğu için basılı yayın okumayı tercih ettiğini belirten katılımcı sayısı ise yedi kişidir (f: 7). Basılı kitabı daha gerçekçi bulanların sayısı dört iken, basılı metinleri daha erişilebilir (f: 2) ve keyifli ( $f: 1)$ bulanlar da son iki sırayı paylaşmaktadır.

Birçok araştırmacıya göre dijital erişim imkânlarının çoğalması, gençlerin dijital dünya ile gitgide daha fazla etkileşim halinde bulunması durumu, onların kitap okuma alışkanlıklarının da dijital metinler yönünde değişeceği şeklindedir (Boesken, 2002; Chaouli, 2013; Duran \& Alevli, 2014; Franzmann, 2001; Karolak, 2002; Schön, 1995). Fakat bu anketin sonuçlarından da anlaşılacağı üzere, üniversitede yabancı dil edebiyat bölümü okumakta olan mezun olma adayı öğrencilerin tercihleri son tahlilde mutlaka basılı metinler üzerinde yoğunlaşmaktadır. Bu konuda öğrencilerin sunmuş oldukları gerekçeler de makul gerekçeler olarak değerlendirilebilir.

\section{4. Öğrencilerin Türkçe Kitap Okuma Alışkanlığı Olup Olmadığı}

Sadece edebiyat bölümü öğrencilerinin değil, genel olarak üniversite öğrencilerinin güçlü okuma alışkanlıklarına sahip olması, hayatın da olağan akışı çerçevesinde beklenen bir durumdur (Yılmaz \& ark, 2009: 22). Dolayısıyla bu soruya toplam 107 öğrencinin 102'inin olumlu yanıt vermiş olması, onların en azından ana dillerinde belli bir okuma kültürüne sahip olduğunu ve bu alışkanlığı öğrenimini görmekte oldukları yabancı dil alanında da kullanacakları varsayılabilir.

\subsection{Yılda okunan Türkçe kitap sayısı}

Bir önceki soruya verilen cevabın sınaması olarak katılımcılara anadillerinde yılda kaç kitap okudukları sorulduğunda alınan cevaplar aşağıdaki tabloda gösterilmektedir.

Tablo 3

Katılımcıların yılda kaç kitap okuduklarını gösteren tablo

\begin{tabular}{ccccc}
\hline 10'dan az & 11-20 arası & 21-30 arası & 30'dan çok & Hiç okumayan \\
\hline$f: 43-(\% 46.1)$ & $f: 32-(\% 34.24)$ & $f: 27-(\% 28.89)$ & $f: 13-(\% 13.91)$ & $f: 9-(\% 9.63)$
\end{tabular}


Tablodaki sonuçlar incelenecek olursa, her üç edebiyat bölümünden ankete katılan öğrencilerin bir önceki soruya verdikleri yanıtın bu soruya verilen yanıtlar ile tutarlılık gösterdiği görülebilir. Bu bağlamda, ankete katılanların beyanlarına göre yıllık kitap okuma sayıları araştırmacının beklentisinin üzerindedir. Odabaş v.d.'nin (2008: 436) yapmış oldukları çalışmada, okuma alışkanlığı düzeylerini okuyucuların yıl içerisinde okudukları kitap sayısına göre üç aşamada sınıflandırdıkları görülmektedir. Buna göre;

- $\quad$ Az okuyan okur tipi: yılda 5 ve daha az sayıda kitap okuyanlar,

- $\quad$ Orta düzeyde okuyan okur tipi: yılda 6 ila 11 arasında kitap okuyanlar,

- $\quad$ Çok okuyan okur tipi: yılda 12'den fazla kitap okuyanlar.

Bu görüşe göre, anket katılımcısı olan 107 kişinin yarıdan fazlasının çok okuyan okur tipine göre sınıflandırılabileceği söylenebilirken, 43 öğrenci de orta düzeyde okuyucu olarak adlandırılabilir.

\section{6. Öğrenim Görülen Bölüm ile İlgili Türkçeye Çevrilmiş Olan ya da O Yabancı Dilde Orijinal Eser Okunup Okunmadığı Konusu}

$\mathrm{Bu}$ soruya dair verilen yanıtlarda öğrencilerin tamamına yakını $(f: 101)$ öğrenim gördükleri dilde ya da söz konusu dilde yazılıp Türkçeye çevrilmiş eserleri okuduklarını beyan etmiştir. Bu soruya verilen yanıtların bu denli olumlu olması, öğrencilerin söz konusu eserleri belki de aldıkları derslerin birer konusu olarak okumuş olabilecekleri düşüncesini akla getirecektir. Bu yüzden söz konusu tarzda kitap okunup okunmadığından ziyade adı geçen tarzda öğrenim gördükleri alanda kaç kitap okudukları da öğrencilere sorulabilecek bir diğer soru olabilir. Bu yüzden öğrencilerin gerçekten okuma alışkanlıklarının bir sonucu olarak mı, yoksa ders gereği mi bu kitapları okuduğunu test edebilmek için anket içerisinde yöneltilmiş olan diğer sorulara verilen yanıtları da dikkate almak gerekecektir. Fakat sayının bu denli yüksek olması, gençlerin entelektüel gelişim süreçlerine yatırım yapmakta olduklarının bir göstergesi olarak her hâlükârda sevindirici bir neticedir denebilir.

\section{7. Öğrenim Görülen Bölüm ile İlgili Kitap Haricinde Okunan Metin Türleri}

Öğrencilerin öğrenim gördükleri dilde kitaptan başka ne okudukları sorulduğunda verdikleri yanıtlar aşağıdaki tabloda sunulmuştur. 
Tablo 4

Öğrenim görülen dilde kitap dışında okunan metin türleri

\begin{tabular}{cccccc} 
e- Dergi & e- Makale & e- Gazete & Bilim kurgu & Şiir & \\
$f: 21$ & $f: 19$ & $f: 17$ & $f: 11$ & $f: 7$ & \\
\hline Tarih & Kişisel gelişim & Araştırma & Kısa öykü & Tweet, Caps, Okumuyorum \\
yazıları & yazıları & yazıları & & Karikatür & \\
$f: 7$ & $f: 6$ & $f: 6$ & $f: 4$ & $f: 4$ & $f: 5$ \\
\hline
\end{tabular}

Tabloda sunulan sonuçlara göre 21 öğrenci, ilgi alanlarına hitap eden ve öğrenim görmekte olduğu dilde yayımlanan e-dergileri okumaktan hoşlandığını belirtmiş, 19 öğrenci ise e-makale okuduğunu belirtmiştir. Söz konusu makalelerin nitelikleri incelendiğinde ise öğrencilerin bu soruya verdikleri nitel cevaplardan yola çıkarak söz konusu makalelerin, onların ilgi alanlarına hitap eden konularda, gazete ve dergilerde köşe yazısı olarak yayımlanan makaleler olduğu anlaşılmıştır. Tabloda dikkat çeken bir diğer sonuç ise, yabancı dil edebiyat bölümü son sınıf öğrencilerinin 17 tanesinin öğrenim görmekte oldukları dilde e-gazete okuma yönünde alışkanlık sahibi olmasıdır. Bunu 11 kişi ile bilim kurgu yazıları, 7'şer okuyucu ile de şiir ve tarih ile ilgili yazıları okumakta olanlar gelmektedir. Öğrenim görmekte oldukları dilde kişisel gelişim ve araştırma yazılarını da okumayı tercih edenlerin sayısı eşittir (f: 6). Son sırada ise 4'er kişinin yabancı dilde okumayı tercih ettiği kısa öykü, caps, tweet ve karikatür türleri yer almaktadir.

$\mathrm{Bu}$ sonuçlardan yola çıkarak, Tekirdağ Namık Kemal Üniversitesi Fen-Edebiyat Fakültesi yabancı dil edebiyat bölümü son sınıf öğrencilerinin öğrenim görmekte oldukları Almanca, Fransızca ve İngilizce dillerinde kitap dışında çok farklı alanlarda yabancı dilde yazılmış metinleri okuma eğilimi gösterdikleri söylenebilir. Bu sonuç da söz konusu öğrenci kitlesinin okuma alışkanlığının sadece kitap üzerinde yoğunlaşmadığını, bilakis öğrencilerin farklı ilgi alanlarına göre de yabancı dilde metin okumaya eğilim gösterme yolunda olduğunu ortaya koymaktadir. 


\section{8. Öğrenim Görülen Bölüm ile İlgili Eserlerin Kişilik Gelişimine Katkısı Olup Olmayacağı Konusunda Görüşıler}

Şekil 1

Bölüm ile ilgili eserlerin kişilik gelişimine katkısı ile ilgili grafik

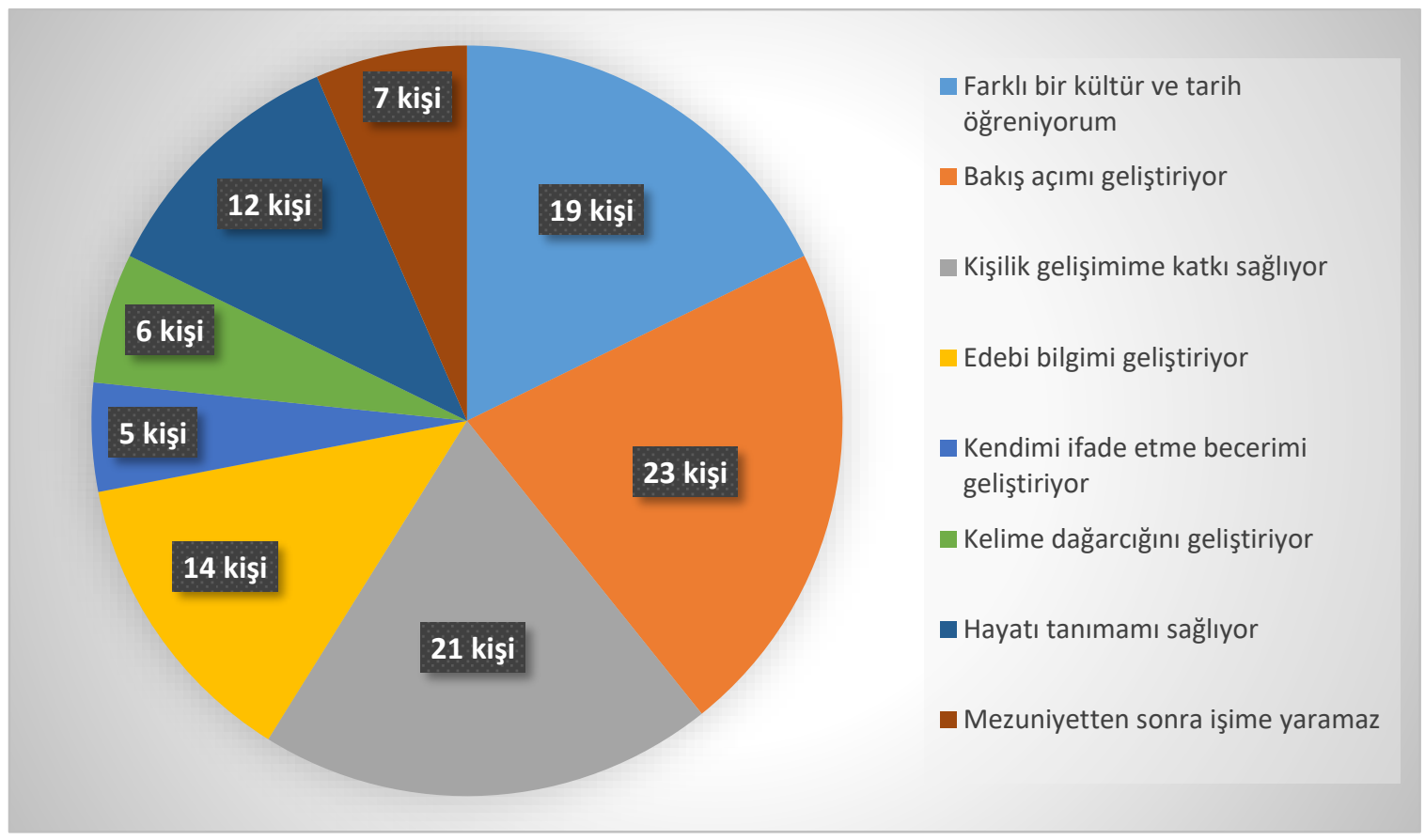

Bu soruya 100 öğrenci olumlu yanıt verirken, 7'si olumsuz yanıt vermiştir. Öğrenciler, bölümlerinde öğrenimini gördükleri yabancı dilde yazılmış olan edebî eserlerin ve diğer metinlerin kişilik gelişimlerini olumlu şekilde etkilediğini yedi ana başlık altında özetlemiştir. Fakat sadece yedi öğrenci bölümü ile ilgili olarak okumak durumunda kaldığı kitapların mezuniyetten sonra hiçbir işine yaramayacağını belirtmiştir.

$\mathrm{Bu}$ soruya verilen olumlu yanıtlar incelendiğinde, özellikle "Kelime dă̆arcı̆̆ımı geliştiriyor" ve "Kendimi ifade etme becerimi geliştiriyor" ifadeleri, katılımc1ların yabancı dil bilgilerini geliştirmek amacıyla da yabancı dilde okumalar yapmaya olumlu baktıkları şeklinde yorumlanabilir. Günümüzde yabancı dilde öğrenim faaliyetinde bulunmakta olan dil ve edebiyat bölümü öğrencilerinin, öğrenim gördükleri yabancı dili büyük oranda -İngilizce hariç olarak- üniversitede öğreniyor olması, onların yükseköğrenim hayatları boyunca söz konusu dildeki becerilerini geliştirmelerini de gerekli kılmaktadır. Dolayısıyla yukarıda anılan iki önemli ifade, öğrencilerin üniversite son sınıfa geldiklerinde dahi dil becerilerini geliştirmek yönünde çabalarının olduğunun bir göstergesi olarak ele alınabilir. Öğrenciler safhada yabancı dilde farklı metin türleri okumayı bir etken olarak görmektedirler. 


\section{9. Öğrenim Görülen Bölüm ile İlgili Kitap Okunmamasının Sebepleri}

$\mathrm{Bu}$ soruyu öğrencilerin büyük çoğunluğu yanıtlamamıştır. Fakat soruya verilen 36 yanıta bakılacak olursa, 13 kişinin bölüm ile ilgili kitap okumamasının sebebi olarak yabancı dil bilgilerinin söz konusu kitapları anlama konusunda yeterli olmadığı anlaşılır. 6 öğrenci ise kitap okuma tercihinin ders dışı konular ile ilgili kitaplardan yana olduğunu dile getirmiştir. $\mathrm{Bu}$ sonuç, söz konusu 6 kişinin daha ziyade okuduğundan haz almayı istedikleri ve kendi seçebildikleri metinleri okumayı tercih edebileceklerini düşündürtmektedir. Nitekim Bayat ve Çetinkaya (2018: 986)'ya göre de haz için okuma, bireylerin kişisel seçimleri sonucunda gerçekleşen bir edimdir ve "belirli bir yerle ve zamanla sınırlandırılması güç olan bu tür okumanın tanımında okul bağlamından 'sıyrılma'(!) göze çarpar”.

Mecbur kılınma, bu öğrenciler için okuma faaliyetini kendileri adına motivasyon düşürücü bir etken haline getirmektedir. Ankete katılan 7 kişi ise edebiyat bölümü öğrencisi olmasına rağmen, edebî eserlerin sıkıcı olduğunu belirtmiş ve bu sebepten dolayı bölüm ile ilgili kitap okumadığını dile getirmiştir. Fakat bu sonuç, söz konusu öğrencilerin hiçbir okuma alışkanlığına sahip olmadıkları anlamına gelemez. "Çünkü üniversite öğrencisi, profesyonel bir öğrenci olmalıdır. Sadece ders çalışan not ezberleyen bir canlı türü değildir” (Yılmaz \& ark, 2009: 29). Bu düşünce ile bundan önceki sorulara verilen yanıtlar da göz önüne alınarak, bu soruya kitap okumama sebeplerini ders ile ilişkilendiren anket katılımcılarının ders içeriği haricinde çok farklı türde metinleri okuma eğiliminde olabilecekleri de değerlendirilebilir.

5'er öğrenci ise bu konuda yeterli motivasyonu olmadığını ya da yeterli zamanı olmadığı için bölüm ile ilgili yabancı dilde yazılmış kitap okumayı tercih etmediğini belirtmiştir.

Şekil 2

Öğrenim görülen bölüm ile ilgili kitap okunmamasının nedenleri ile ilgili grafik

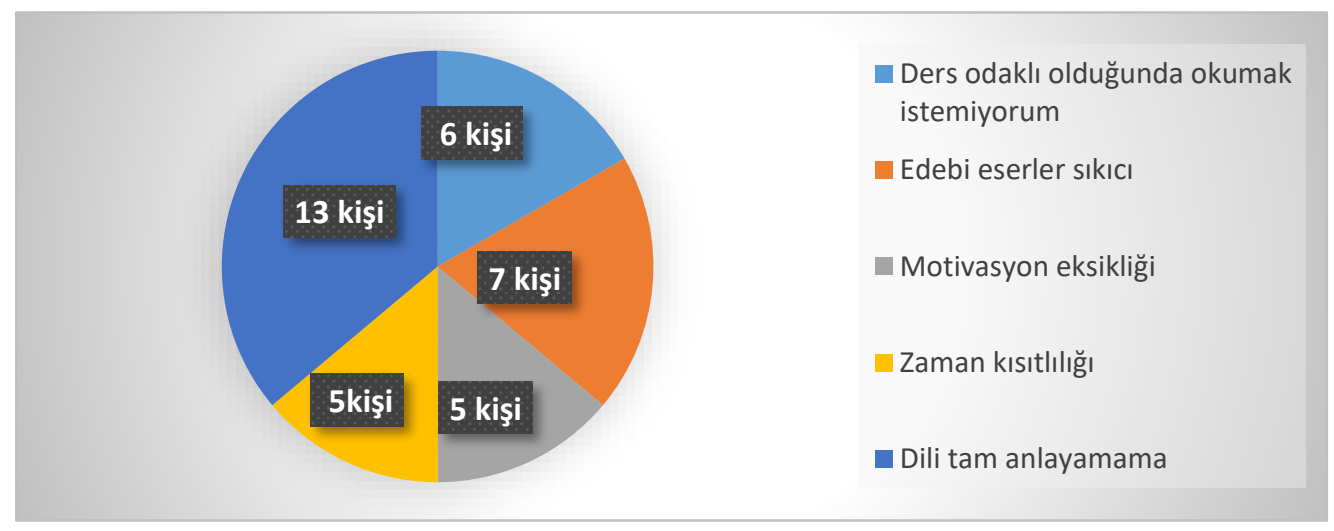


Yukarıda açıklanan sebepler göz önüne alındığında yabancı dil edebiyat bölümlerinde öğrencilere okutulan edebî alan kitaplarının dilinin, öğrencilerin yabancı dil bilgileri de dikkate alınarak seçilmesi uygun olabileceği gibi, öğrencileri bu tür kitapları okuyabilecek dil yetisine sahip olarak yetiştirmenin ya da bölüme öğrenci alımında yeterli dil seviyesine sahip adayların bölüme dâhil edilmesi önerisi de tartışılması gereken diğer konular olabilir.

Bunun yanında genel anlamda öğrencilerin motivasyon eksiklerinin giderilip, edebiyatın sevdirilmesi konusunda ise bölümler bazında aktiviteler ve özendirici faaliyetlerin çeşitlendirilip arttırılmasında fayda olacaktır.

\subsection{Bölüm İçerisinde Kitap Okumaya Teşvik Edici Faaliyetler ya da Kişiler Olup Olmadı̆̆}

Öğrencilere sunulan anketin bu sorusuna gelindiğinde 93 kişinin bölümdeki eğitimöğretim yılları içerisinde kitap okumaya farklı şekillerde yönlendirilmeye çalışıldıkları görülmektedir. Unutulmamalıdır ki bu sonuç da diğer sorulara verilen cevapların sonuçları gibi ankete katılım sağlayan her üç bölüm öğrencilerinin beyanlarından derlenmiştir. Bölümlerinde öğrenim gördükleri süre içerisinde kitap okumaya özendirici faaliyetler olarak öğrenciler tarafından ele alınan noktalar şu şekillerde dile getirilmiştir;

a- Hocalarım hediye kitap verdiler.

b- Hocalarımın ilgi çekici eser önerileri oldu.

c- Hocalarım derslerde alan ile ilgili farklı kitap sunumları yaptırdılar.

d- Hocalarım filmi çekilen eserleri söylüyorlardı.

e- $\quad$ Hocalarımın okuduğunu görmek beni de teşvik etti.

f- Hocalarım yanımızda hep bir kitap olmasını öğ̈̈tlediler.

g- Hocalarım derse kitap ile geliyorlar.

h- Hocalarım kitapların konularını gerçek hayat ile örnekleyerek açıkladılar.

Görüldüğ̈ gibi son sınıf öğrencilerinin üniversitede geçirdikleri yıllar boyunca derslerine giren öğretim elemanları tarafından bilinçli ya da bilinçsiz olarak yabancı dilde kitap okumaya teşvik edilmesini sağlayan birtakım yararlı alışkanlıklar ve aktivitelerin yine öğrencilerin bakış açısı ile dile getirilmesi, Türkiye’ deki diğer edebiyat bölümlerinin öğretim elemanları için de bir örnek teşkil edebilir. "Esasen okuma alışkanlığı kazandırılması ve yabancı dilde okumanın öğrenciye sevdirilmesi çerçevesinde araştırmacıların birleştiği temel 
noktalardan biri öğrencilerin okumaya yönelik geliştirdikleri tutumlar üzerinde öğretmenlerin okumaya yönelik tutumlarının etkili olduğudur” (Pekkanlı \& Kartal, 2010: 102). Solmaz (2018: 606)'a göre de “öğretmen konumundaki kimseler, öğrenenlere okuma alışkanlığı kazandırma konusunda en etkili kimselerdir". Sonuç olarak yukarıda sıralanan noktaların bizzat öğrencilerin düşüncesi olması da bu çalışmanın özgün yönlerinden birini ortaya koymaktadır.

Araştırmaya dayalı her çalışmada olduğu gibi bu çalışmada da sorulara verilen yanıtlar tümüyle olumlu yönde olmamıştır. Söz konusu soruya 14 öğrenci olumsuz yanıt vererek, öğrenim hayatları boyunca derslerine giren öğretim elemanları tarafından yabancı dilde okumaya teşvik edilmediklerini aşağıdaki ifadelerde dile getirmiştir.

a- $\quad$ Hocalar bu konu ile ilgili değildiler.

b- Özet okumanın daha mantıklı olduğunu öğütleyen hocalar oldu.

c- Hocaların bazıları bizleri okumak zorunda biraktı.

Alınan bu olumsuz görüşler ise ankete konu olan bölümler içerisinde derslerde agresif tutum sergileyebilen birtakım öğretim elemanlarının olabildiğinin de göstergesidir. Fakat ortaya çıkan bu sonuç da söz konusu öğretim elemanlarına kendi akademik duruşlarını ve bulundukları konumdaki var oluş sebeplerini bir dış göz vasıtasıyla yeniden gözden geçirmeleri konusunda destek olabilmelidir.

\subsection{1. Öğrenciler Lisans Eğitimine Başlanan Zamandan Bu Yana Daha Çok Okur Hale}

\section{Geldi mi?}

$\mathrm{Bu}$ sorunun amacı, genel olarak tüm metin türleri göz önüne alınarak öğrencilerin okuma alışkanlıklarının gelişiminde lisans eğitiminin olumlu etkisi olup olmadığının tespit edilmesidir. Soru, öğrencilerin daha çok ana dilde mi, yoksa yabancı dilde mi okuduklarını sorgulamamaktadır. Daha ziyade lisans eğitimlerinin onların okuma alışkanlıklarında anlamlı bir fark yaratıp yaratmadığı konusunda fikir almak amacı ile hazırlanmış genel bir sorudur. Sonuçlara bu açılardan yaklaşıldığında, ankete katılım sağlayanlardan 73’ü lisans eğitimlerinin başından sonuna dek geçen süre göz önüne alındığında daha çok okur hale geldiğini belirmiştir. 34 öğrenci ise bu konuda olumsuz yanıt vererek söz konusu süre içerisinde eskisinden daha çok okur duruma gelmediğini belirtmiştir.

$\mathrm{Bu}$ soruya verilen yanıtlar, önceki sorulara verilen yanıtlar ile karşılaştırıldığında, öğrencilerin genel anlamda okuma alışkanlığına sahip olduğunu, hatta büyük çoğunluğun okuduğu bölümün de etkisi ile okuma alışkanlıklarında olumlu gelişme gösterdiği söylenebilir. 


\subsection{2. Öğrencilerin Yabancı Dilde Kitap Okumasını Olumlu Etkileyen Faktörler}

Ankete katılanlara yöneltilen son soru ise öğrenimini gördükleri yabancı dilde kitap okumalarını olumlu yönde etkileyen faktörlere değinmeleriydi. Üç farklı dil ve edebiyat bölümündeki 107 öğrenciden elde edilen nitel veriler 1şı̆̆ında, söz konusu faktörlerin oldukça fazla olduğu tespit edilmiştir. Almanca, Fransızca ve İngilizce dillerinde edebiyat öğrenimi gören son sınıf öğrencilerine göre yabancı dilde kitap okumalarını etkileyen faktörler aşağıda sıralanmıştır.

Yabancı dil bilgisinin gelişimi:

- Yabancı dilde konuşma ve yazma becerimin gelişeceğine inancım.

- Kelime hazinemin ve telâffuzumun gelişeceğine inancım.

- Yabancı dilde okumamın gelişeceğine inancım.

- $\quad$ Kitabın dilinin çok ağır olmaması. Onu anlayabilmem.

Entelektüel kişilik gelişimine katkı:

- $\quad$ Yeni şeyler öğrenmek için meraktan.

- Okumanın benim için bir alışkanlık olması.

- Okumanın ilham verici olması.

- Yazarı tanımak istemem.

- $\quad$ Hayata dair dersler veren bir kitap olması.

Diğer diş etkenler:

- $\quad$ Yakın çevremde herkesin okur olması.

- $\quad$ Gerçek dünyadan bir süreliğine soyutlanmak ve dinlenmek.

- Kitaplar hakkında tavsiyeler almak.

- $\quad$ Okuduğum bölüm ve hocalarım.

Yukarıda maddeler halinde özetlenmeye çalışılan sonuçlardan da anlaşılacağı üzere, her ne kadar son sınıf öğrencisi olsalar da öğrencilerin yabancı dilde kitap okuma amaçları arasında hazırlık sınıfı dâhil en az beş yıl öğrenimini gördükleri yabancı dil konusunda bilgi ve becerilerini geliştirmek öne çıkan bir başlık olmuştur. Bu durum çalışmanın bir sonucu olarak, yabancı dil ile eğitim vermekte olan dil - edebiyat bölümlerinde öğrenim görmekte olan 
öğrencilerin yabancı dil seviyelerinin son sınıfta dahi kaynak dilde yazılmış olan edebî eserleri okumakta yetersiz kalabildiğini tespit etmek açısından da önemli bir gösterge olabilir.

Öte yandan ikincil olarak tespit edilen başlık ise her üç bölümden de ankete katılım sağlayan öğrencilerin yabancı dilde kitap okumanın entelektüel boyutunun farkında oldukları ve bunu kendileri için ayrı bir motivasyon kaynağı olarak görüyor olmalarıdır. Okuma alışkanlığının içsel bir süreç olduğu gerçeğinden yola çıkarak, bu başlık altında yer alan ifadelere bakıldığında, anket katılımcılarının yabancı dilde okuma yapmaları adına birçok olumlu görüşe sahip olmaları, onların gelecek yaşantıları adına umut verici bir farkındalıktır. Anket sonucunda elde edilen veriler ile paralel olarak, okuma etkinliğinin alışkanlık halini almış olması Koç ve Müftüoğlu (2008: 62)'na göre de “bireyin davranışları ve başkalarıyla ilişkilerini yönlendiren, iç dünyasını zenginleştiren, bireyin hayata bakış açısını genişleten, onun çevresine önyargısız bakmasını sağlayan, beğeni düzeyini artıran, düşünme ve yaratma özgürlüğ̈̈ ile değerlendirme alışkanlığı kazandıran bir süreçtir”.

Son olarak, öğrencileri yabancı dilde kitap okumaya iten dış etkenler altında sıralanan dört alt maddenin ise her biri ayrı ayrı ele alınabilecek niteliğe sahiptir. Kişinin yakın çevresindeki okur sayısının fazla olması, onda küçük yaştan başlayarak zaten belli bir okuma kültürünün gelişmiş olduğunun göstergesidir. Esasen "okuma alışkanlığının biçimlendiği ilk ortam da ailedir" (Genç, 1995: 74). Çalışmanın giriş kısmında da belirtildiği üzere, okuma alışkanlığı kazanmak bazen yıllar alabilen bir süreçtir. Bu alışkanlığın kazanılması için sürece ne kadar erken başlanırsa o kadar yol alınır. Fakat söz konusu olan yabancı dilde yazılmış kitapların okunması ise, dil öğrenmeye başlandıktan sonra her firsatta okuma alıştırmaları yapılması dil seviyesi ilerledikçe genel okuma alışkanlığı temelinde çok da zorlayıcı bir aktivite olmayacaktır. Bunun yanında yabancı dilde nelerin ne zaman okunması gerektiği dersin öğretim elemanları tarafından yapılacak tavsiyeler ile şekillenebilir. Bu şekilde öğrenen kişinin dil gelişim seviyesine göre kitaplar seçilip tavsiyelerde bulunulabilir. Böylece okuyucu okuduğundan zevk almaya başlayacaktır. İnsan da esasen ancak okumaktan zevk alındığında dünyadan soyutlanmış ve dinlenmiş hissedebilir.

Konuya bu bakış açısından yaklaşılacak olursa, ana dilde olduğu kadar yabancı dilde de okuma alışkanlığı kazanımında dış faktörlerin ne denli önem arz ettiği aşikârdır. 


\section{SONUÇ VE ÖNERILER}

Ülkemizde günümüz “Türk toplumunun genel olarak az okuyan bir toplum” olduğu görüşü sıkça dile getiriliyor olsa da (Genç, 1995: 71; Pekkanlı \& Kartal, 2010: 102), bu araştırmadan elde edilen sonuçlar 1şığında, en azından fen-edebiyat fakültesi yabancı dil edebiyat bölümü öğrencilerinin eğitimlerinde edindikleri prensiplerin de 1şında mezuniyet seviyesine geldiklerinde belirli bir okuma disiplini edinebildikleri görülmektedir. Bu okuma disiplini anket katılımcılarının sadece ana dillerinde değil, yükseköğrenim hayatları boyunca öğrenimini gördükleri yabancı dilde de çok farklı metin türleri çerçevesinde geçerlidir denebilir. Çalışmaya konu olan Alman, Fransız ve İngiliz dili ve edebiyatı bölümü öğrencilerine uygulanan anketin diğer sonuçları aşağıda maddeler halinde sıralanmıştır:

- Ankete katılım sağlayan öğrenciler tarafindan en çok okunan kitap türü olarak romanlar öne çıkmaktadır. Roman türü olarak ise klasiklerin diğer roman türlerine göre daha çok tercih edildiği görülmektedir. Bu türü felsefe, tarih ve kişisel gelişim kitaplarının izlediği tespit edilmiştir.

- Öğrenciler okudukları metin türlerini ya da kitapları en çok elden satın alma yolunu tercih etmekteler. Bunun yanında ikinci popüler temin yolu ise dijital ortamlardır. Fakat anlamlı sayıda öğrenci ise üniversite kütüphanesini okuma metni ya da kitap temini konusunda kaynak olarak görmektedir. Beş öğrenci korsan kitap satın aldığını belirtmiştir.

- Her üç bölüm öğrencilerinden elde edilen verilere göre öğrencilerin çoğunluğunun özellikle kitap türündeki metinleri basılı şekilde okuduğu tespit edilmiştir (f: 87).

- Ankete katılan 107 öğrencinin 102’si düzenli okuma alışkanlığına sahip olduğunu belirtmiştir. Bu yanıta dayanarak öğrencilere yılda kaç adet kitap okudukları sorulduğunda öğrencilerin yarıdan fazlasının çok okuyan okur tipine uygun özellikler sergilediği görülmüştür. Büyük bir kısım öğrenci grubu ise orta düzey okuyucu kategorisinde değerlendirilmiştir. Az okuyan okur tipinde değerlendirilebilecek öğrenci sayısı ise dokuzdur.

- 101 öğrenci öğrenim gördükleri yabancı dilde yazılmış, fakat Türkçeye çevrilmiş olan ya da yazıldığı dilde orijinal olarak okudukları kitaplar olduğunu belirtmiştir. Bu soruya dair alınan olumlu yanıtın, aslında öğrencilerin genel okuma alışkanlıklarından kaynaklı değil de derslerinin içeriği dolayısıyla okunan kitaplara yönelik verildiği düşünülmektedir.

- Öğrenimi görülen yabancı dilde kitap haricinde ne tür metinler okunduğu sorulduğunda yanıtlarda e-dergi, e-gazete, e-makale, caps, karikatür ve tweet şeklinde aslen dijital ortam 
kaynaklı metinlere yönelen öğrenci sayısının ankete katılan toplam öğrenci sayısının yarısından fazlası olduğu tespit edilmiştir (f: 60). Bu durumda ankette yöneltilen önceki sorulardan elde edilen cevaplar da göz önüne alınacak olursa, öğrencilerin yarıdan fazlasının kitap şeklinde metinleri basılı ortamda okumayı tercih ettiği, fakat bunun dışındaki metinleri ise dijital ortamda ekrandan okumayı tercih ettiği söylenebilir.

- Öğrenciler, öğrenim gördükleri dilde okudukları metinlerin kişilik gelişimlerine özellikle entelektüel açıdan katkı sağlayacağı görüşündedir. Fakat bunun yanında yabancı dilde okunan kitapların ve diğer metin türlerinin yabancı dil bilgisinin gelişimi anlamında da kişiye katk1 sağlayacağı görüşü öğrenciler arasında hâkimdir. Sonuç olarak ankete katılım sağlayan öğrencilerin öğrenim gördükleri yabancı dili büyük oranda -İngilizce hariçüniversitede öğreniyor olması, onların yükseköğrenim hayatları boyunca söz konusu dildeki becerilerini geliştirmelerini de gerekli kılmaktadır.

- Öğrenim görülen dilde neden kitap okumadığı konusuna değinen az sayıda öğrenci olmasına rağmen $(f: 36)$, elde edilen veriler şu beş başlık altında toplanmıştır; metin ders odaklı olduğunda, edebî eser okumak sıkıcı olduğundan, motivasyon eksikliğinden, okumak için yeterli zamanın bulunamamasından, metnin yazıldığı yabancı dili tam olarak anlayamamaktan.

- Anket katılımcısı olan öğrenciler, öğrenim gördükleri bölümde kitap okumaya teşvik edilmeleri bağlamında öğretim elemanları tarafından büyük ölçüde desteklendiklerini belirtmiş olsalar da bu konuda kesinlikle şevklerini kıran bazı hocalarının olduğunu da dile getiren bir grup söz konusudur. Ankete katılım sağlayan öğrenciler üç farklı bölümün öğrencisi olduğundan, söz konusu öğretim elemanlarının da her üç bölümde var olabileceği varsayılmaktadır.

- Ankete katılan 73 öğrenci lisans eğitimine başladıkları zamandan bugüne kadar daha çok okur hale geldiğgini belirtmiş, 34 öğrenci ise kendi kitap okuma alışkanlıklarında herhangi bir ilerleme gözlemlemediğini dile getirmiştir. Bu sonuca göre, öğrenim görülen edebiyat bölümlerinin her üçünün de genel anlamda öğrencilerinin okuma alışkanlıklarının gelişmesinde önemli derecede olumlu rol oynadığı söylenebilir. Fakat sadece bu sonuç temel alınarak öğrencilerin çoğunluğunun öğrenim gördükleri dilde de daha fazla okur hale geldiği söylenemez. Çünkü öğrenciler, bir önceki soruda söz konusu metinleri ve kitapları okumak için yabancı dil bilgilerinin yeterli olmadığını açıkça dile getirmiştir. 
- Almanca, Fransızca ve İngilizce dillerinde edebiyat öğrenimi gören son sınıf öğrencilerinden elde edilen veriler ışığında, yabancı dilde metin okunmasını olumlu yönde etkileyen faktörler üç ana başlık altında toplanmıştır. Bunlar; yabancı dilde okunan metinlerin öğrencinin yabancı dil bilgisinin gelişimine katk1 sağlayacağı görüşü, yabanc1 dilde yazılmış metinlerin okunmasının öğrencinin entelektüel kişilik gelişimine katkı sağlayacağ1 görüşü, yakın çevrenin olumlu etkisi, gerçek dünyadan soyutlanma hissine kapılma, bölüm hocalarının olumlu etkisi gibi dış etkenlerdir.

Uygulanan anketten elde edilen sonuçlar makro çerçevede yorumlanacak olursa, öğrencileri yabancı dilde okumaya yönelten etkenlerin içerisinde okuma çalışmalarının yabancı dil bilgisinin gelişmesine olumlu katkı sağlayacağını düşünüyor olmalarının geldiği dikkat çekmektedir. Söz konusu öğrenci kitlesi özellikle İngilizce dışında Alman ve Fransız dilini üniversite yıllarında öğrenmektedir. Hazırlık sınıfında alınan yabancı dil eğitimi temeli ile bir yabancı dil edebiyat bölümünden mezun olmak, ancak tüm yükseköğrenim yılları boyunca istikrarlı bir dilsel gelişim sergilendiği sürece gerçek anlamda başarıya ulaşmıştır ve anlamlıdır denebilir. Konuya bu bağlamda yaklaşıldığında ankete katılan son sınıf öğrencilerinin mezun olmalarına az bir süre kalmasına rağmen, halen yabancı dil becerilerini geliştirmeye çalışmaları ve bunu okuma anlama yoluyla çok farklı metin türleriyle de destekliyor olmaları memnuniyet verici bir durum olarak değerlendirilmektedir.

Aşağıda sunulan öneriler, hem öğrencilerin yabancı dil bilgi ve becerilerinin gelişimi, hem de edebiyat bölümü öğrencilerinin genel niteliklerinin gelişimi adına üniversite yılları boyunca onlara sağlanabilecek destekler üzerine yoğunlaşmıştır. Bu çerçevede araştırmanın sonuçlarına yönelik öneriler aşağıdaki gibi sıralanabilir:

- Öğrenciler tarafından en çok okunan tür olduğu anlaşılan romanlar, bölümlerde öğrencilere sadece klasik roman türleri olarak değil aynı zamanda bilim kurgu, fantastik, psikolojik, macera, gerilim, deneme, romantik, yer altı edebiyatı gibi türleri içerecek şekilde sunulabilir. Eğer bu alt kategorilerde yer alan roman türlerinin tanıtımı, incelenmesi gibi konular bölüm ders müfredatında yer almıyorsa üzerinde çalışılarak mutlaka ders müfredatlarındaki yerini almalıdır.

- Anketten elde edilen veriler 1şığında öğrencilerin kitap ve metin temininde en çok başvurdukları ikinci yöntemin dijital ortam olduğu tespit edilmiş̧tir. Buna göre, bölüm içerisinde sunulan ders etkinliklerinde dijital edebiyat, medyada edebiyat, ekrandan okuma, internet romanları, v. b. güncel konulara da yer verilmelidir. 
- Anket katılımcılarının kitap haricindeki metinleri okuma ortamının genel olarak dijital ortamlar olduğu yorumundan yola çıkarak, edebiyat derslerinde dijital ortamda nitelikli metinleri seçme konusunda öğrencilere bilgiler verilmesi ve böylece edebiyat öğrencilerinin okumada niceliğin değil, niteliğin öneminin farkına varmaları sağlanmalıdır.

- Her üç bölüm öğrencilerinin de kendi ana dilinde belirli bir okuma kültürüne sahip oldukları tespit edilmiştir. Fakat öğrencilerin eğitimini aldıkları yabancı dilde de aynı derecede okuma alışkanlığı veya kültüre sahip olduklarını söyleyebilmek için öğrenim süreleri boyunca her dönem okuma yarışmaları, okuma sunumları, okudukları eserler ya da metinler ile ilgili poster sergileri, yazar davetleri, video çekimleri yapmaları, eser tanıtım yazıları yazmaları ve bunları bölüm dergisine taşımaları vb. etkinliklere yer verilmesi önerilir.

- Öğrencilerin kitap haricinde çok farklı türlerde metinler okudukları tespitinden yola çıkarak, hazırlık eğitimlerinden başlamak üzere, derslerde klasik edebî eserlerin haricinde öğrencilerin ilgi alanlarına hitap eden metinlere de yer verilmesi önerilir. Metin inceleme çalışmalarında en az 5 farklı çeşit metin türüne ayrıntıları ile yer verilmesi öğrencilerin okuma motivasyonlarının yükseltilmesi açısından anlamlı görülmektedir.

- Edebiyat bölümü öğrencilerinin kendini yabancı dilde ifade edebilme becerilerinin ve kelime hazinesinin gelişimi açısından, okunan kısa metinlerin farklı ifadeler ile yeniden aktarılması gibi çalışmalar bir öneri olarak sunulabilir.

- Birçok öğrencinin bölüm ile ilgili olan kitapları okumamasının sebepleri göz önüne alındığında yabancı dil edebiyat bölümlerinde öğrencilere okutulan edebi alan kitaplarının dilinin öğrencilerin yabancı dil bilgileri de dikkate alınarak seçilmesinin uygun olabileceği düşünülmektedir. Öğrencileri bu tür kitapları okuyabilecek dil yetisine sahip olarak yetiştirmenin ya da bölüme öğrenci alımında yeterli dil seviyesine sahip adayların bölüme dâhil edilmesi önerisi de tartışılması gereken diğer konular olabilir.

- Anket sonuçlarında maalesef öğrencileri kitap okumaya teşvik etmeyen edebiyat bölümü öğretim elemanlarının da olduğu ortaya çıkmıştır. Bu gibi olumsuz davranış içerisinde olan üniversite öğretim elemanlarının kendi akademik duruşlarını ve bulundukları konumdaki var oluş sebeplerini bir dış göz vasıtasıyla yeniden gözden geçirmeleri konusunda bu araştırmanın sonuçlarını dikkate almaları önemle önerilir.

- Edebiyat bölümlerinde öğrencilere sunulması gereken metin türlerinin yine öğrenciler ile görüş alışverişi yaparak seçilmesi önem arz etmektedir. Çünkü bir okuyucu olarak öğrenci, ancak beğenerek okuduğu metinden haz alacak ve okumayı sevecektir. Söz konusu olan 
yabancı dilde okuma etkinliği ise, bunun önemi bir kat daha artacaktır. Öğrenciye rağmen yapılan okuma çalışmaları uzun vadede etkili ve kalıcı olmayacaktır.

Üniversite öğrencilerin okuma alışkanlıkları üzerine yapılmış olan birçok bilimsel araştırmadan farklı olarak bu çalışma üç yabancı dil bölümünde öğrenim gören edebiyat fakültesi öğrencilerinin katılımı ile gerçekleştirilmiştir. Katılımcıların edebiyat öğrencisi olması ve yabancı dilde okuyor olmaları dolayısıyla onların yabancı dildeki okuma alışkanlıklarına dair veriler toplanmış olmasının ise çalışmaya farklı bir boyut kazandırdığı düşünülmektedir. Bundan sonra yapılacak olan muhtemel çalışmalarda aynı konu özelinde farklı bölümler arasında karşılaştırmalı anket uygulamaları da yapılabilir. Böylece konu daha farklı boyutlardan da ele alınmış olacaktır.

\section{KAYNAKÇA}

Aksaçlığlu, A. G. \& Yılmaz, B. (2007). Öğrencilerin televizyon izlemeleri ve bilgisayar kullanmalarının okuma alışkanlıkları üzerine etkisi. Türk Kütüphaneciliği, 21(1), 3-28.

Arslan, Y., Çelik, Z. \& Çelik, E. (2009). Üniversite öğrencilerinin okuma alışkanlığına yönelik tutumlarının belirlenmesi. Pamukkale Üniversitesi Eğitim Fakültesi Dergisi, (26), 113124.

Baki, A. \& Gökçek, T. (2012). Karma yöntem araştırmalarına genel bir bakış. Elektronik Sosyal Bilimler Dergisi, 11(42), 1-21.

Bayat, N. \& Çetinkaya, G. (2018). Ortaokul öğrencilerinin okuma alışkanlıkları ve tercihleri. İlköğretim Online, 17(2), 984-1001. doi:doi 10.17051/ilkonline.2018.419349

Boesken, G. (2002). Lesen am Computer - Mehrwert oder Verwirrung? Intersuchungen zur „Konkurrenz“ zwischen Buch und Hypertext. Braungart, G. Eibel, K. ve Jannidis, F. (Editörler), Jahrbuch für Computerphilologie 4 (85-114). Paderborn: Mentis.

Chaouli, M. (2003). Kommunikation und Fiktion: Vom Schreiben und Lesen von Literatur im Internet. Weimarer Beiträge, 49(1), 5.

Çoban, A., İleri, T. \& Temir, M. (2018). Üniversite öğrencilerinin kitap okuma alışkanlığına betimsel bir bakış: Amasya üniversitesi örneği. Sosyal Bilimler Dergisi, 5(19), 50-69.

Duran, E. \& Alevli, O. (2014). Ekrandan okumanın sekizinci sınıf öğrencilerinde anlamaya etkisi. Okuma Yazma Ĕ̆itimi Araştırmaları, 2(1), 1-11. 
Durmuşçelebi, M. \& Sarıcaoğlu, A. (2009). Birinci ve ikinci dil okuma becerisi arasındaki ilişki (Erciyes üniversitesi örneği). Eğitim Araştırmalarında Güncel Sorunlar ve Yeni Yaklaşımlar - I.Uluslararası Türkiye Eğitim Araştırmaları Kongresi (1-3 Mayıs 2009). Çanakkale, Türkiye. http://www.eab.org.tr/eab/2009/pdf/212.pdf Erişim tarihi: 30.04.2020.

Franzmann, B. (2001). Lesezapping und Portionslektüre. Veränderungen des Leseverhaltens besonders bei Jugendlichen. Media Perspektiven (2), 90-98.

Genç, A. (1995). Yabancı dilde okuma alışkanlığı. Hacettepe Eğitim Fakültesi Dergisi, 11, 7174.

Göçerler, H., Atik, O. \& Demir, M. (2017). Die Förderung der Lesegewohnheiten mittels neuer Medien im Deutschunterricht für das Leseverstehen. H. Asutay (Editör), Balkan Educational Studies (ss. 264-279). Edirne: Trakya University Publication No: 188.

Karolak, C. (2002). Digitale Literatur und ihre Auswirkungen auf den Leseprozess. Convivium. Germanistisches Jahrbuch Polen (ss. 129-140). Bonn: DAAD.

Koç, S. \& Müftüoğlu, G. (2008). Dinleme ve okuma öğretimi. Web: www.aof.anadolu.edu.tr/kitap/IOLTP/2277/unite04.pdf Erişim tarihi: 25.04.2020.

Odabaş, H., Odabaş, Z. Y. \& Polat, C. (2008). Üniversite öğrencilerinin okuma alışkanlığı: Ankara üniversitesi örneği. Bilim Dünyasl, 9(2), 431-465.

Pekkanlı, İ. \& Kartal, E. (2010). Yabancı dil öğretmen adaylarının anadil ve yabancı dilde okuma alışkanlıkları üzerine bir araştırma (Uludağ Üniversitesi Eğitim Fakültesi Örneği). Zeitschrift für die Welt der Türken, 2(3), 91-105.

Schön, E. (1995). Lesekultur - Einige historische Klärungen. C. Rosebrock (Editör), Lesen im Medienzeitalter. Biographische und historische Aspekte literarischer Sozialisation. Weinheim: Juventa.

Solmaz, M. (2018). Üniversite öğrencilerinin okuma alışkanlığı üzerine bir araştırma: Yüzüncü Y1l üniversitesi örneği. Türkiye Sosyal Araştırmalar Dergisi, 603-622.

Yılmaz, B., Köse, E. \& Korkut, Ş. (2009). Hacettepe Üniversitesi ve Bilkent Üniversitesi öğrencilerinin okuma alışkanlıkları üzerine bir araştırma. Türk Kütüphaneciliği, 23(1), $22-51$. 


\section{EXTENDED ABSTRACT}

The students of foreign language and literature departments are expected to be good readers because of their field of study. If they do not develop effective reading habits, their education not be considered successful. This study aims to identify senior students' reading habits in the foreign language and literature departments of the Faculty of Arts and Sciences at Tekirdağ Namık Kemal University and to offer solutions to their potential problems. The main goal of the research is to collect data on their reading habits in the target foreign language, but there are also questions on their reading habits in their native language. As expected from the sample group of the research, the universal group is also expected to have developed a certain level of reading habit in the target language. If they have not, the secondary aim is to reveal the factors for not developing reading habits from their perspective and to offer solutions to these problems.

The data collected through the questionnaire is the basis of the research, and senior students were given multiple-choice options while they could add details to each question as well. The questionnaire consisted of 12 questions. It was based on a descriptive scanning model. 31 students from German Language and Literature and 38 students from both French and English Language and Literature departments participated in the research. A total of 107 volunteer students were asked to respond to questions such as: whether they have reading habits, where they obtain their books, whether they prefer digital or analog reading, whether they have reading habits in their native and foreign language, how many books they read annually, what kind of books they prefer to read in a foreign language other than textbooks, the reasons for not reading, and whether they thought reading would contribute to personal development as well as stating the factors encouraging them to read during their higher education.

The survey was developed by the researcher based on the mixed-methods research design (Baki \& Gökçek, 2012). The qualitative data were divided into sub-categories and interpreted accordingly. The survey was treated as a questionnaire rather than a scale, hence reliability was not an issue (Çoban et al., 2018).

The results can be summarised as follows. The students were observed to have acquired a specific reading discipline in their native and the target foreign language. Novels stood out as the most preferred type of books, and among them, classical novels come first. Philosophy, history, and personal development books follow novels. Students prefered to buy 
books, and the second most frequent way of obtaining reading material was via digital media. The majority of students especially read books in printed form. (f: 87). The research showed that 102 of 107 students have regular reading habits. More than half of them exhibit features of the type of readers who read a lot. A large number of students were mid-level readers.

Apart from the books in their target foreign language, more than half of the students participating in the research were inclined towards digital media-originated forms such as emagazines, e-newspapers, e-articles, caps, cartoons, and tweets. $(f: 60)$. - Students think that reading in a foreign language will contribute to their intellectual and personal development as well as foreign language skill development. The reasons for not reading in a foreign language are as follows; lesson-oriented books, tedious literary works, lack of motivation, not having enough time to read, and not being able to fully understand the foreign language in which the text was written. While many lecturers encouraged the students to read books, some lecturers were claimed to discourage them. 73 students stated to have started reading more since starting their undergraduate education.

The factors positively affecting reading in a foreign language were as follows: reading will contribute to language skills and intellectual capacity, the positive effect of the immediate circle, the positive feeling of isolation from the real world, and the positive influence of the lecturers of the department. From a macro perspective, the most crucial factor motivating students to read in a foreign language is its positive contribution to language skills. If the language and literature students have achieved lifelong learning skills, the preparatory class is also meaningful.

In the light of the findings of the current study, the following suggestions can be made: Classical novels, science fiction, fantasy, psychological, adventure, thriller, romantic and underground literature novels, and essays could be integrated in the curriculum. Students secondly prefer digital media, so topics like digital literature, literature in the media, etc. should be included in the courses. In literature courses, students should be educated on choosing qualified sources in the digital environment. Reading contests, presentations, and poster exhibitions about the works they read, author conferences or workshops, video shootings, writing book review articles, and publishing them in the departmental journals could encourage students to read more. Student participation in choosing texts is recommended. Paraphrasing and summarizing skills are observed to help students to develop language skills, so they could be taught at school. Students' language level affects their understanding of theory books. Students should be given more language courses to understand such works, or students with 
higher levels of the target language should be accepted to the department. Each lecturer should engage in activities to encourage students to read. Students should participate in selecting reading materials. If not, the results will not be effective and permanent in the long term. Since the participants are literature and language students, their reading habits in a foreign language adds a different dimension to the study. 